\title{
Identification of copy number variations of chromosomes 7, 9 and 10 in human glioblastomas by SNP-arrays
}

\author{
Inês Crespo ${ }^{1,2^{*}}$, Maria D Tabernero ${ }^{3,4,5}$, Ana B Nieto ${ }^{4}$, Olinda Rebelo ${ }^{6}$, Hermínio Tão ${ }^{7}$, Fernando Gomes ${ }^{7}$, \\ Catarina R Oliveira ${ }^{1,8}$, Maria C Lopes ${ }^{1,2}$, Alberto Orfao ${ }^{4}$
}

From 16th International Charles Heidelberger Symposium on Cancer Research

Coimbra, Portugal. 26-28 September 2010

Glioblastomas (GBM) are the most frequent and malignant tumors of the central nervous system. Despite advances in treatment modalities, their prognosis remains dismal and a better knowledge at the molecular and genomic level is still required.

We have previously reported the cytogenetic heterogeneity of gliomas [1]. The aim of the present study was to identify genetically distinct subgroups of GBM, according to similar copy number $(\mathrm{CN})$ profiles for chromosome 7, 9 and 10, and to establish the prognostic value of the different subsets. We also correlated those genetic subgroups with the clinical and biological features of the tumors.

Single-nucleotide polymorphism (SNP)-arrays (Affymetrix 500K) were performed in a group of $35 \mathrm{GBM}$, to screen for gains, losses, loss of heterozygosity $(\mathrm{LOH})$ and $\mathrm{CN}$ neutral $\mathrm{LOH}(\mathrm{cnLOH})$.

We identified gains of chromosome 7 (97\%) and deletions of chromosome $9(60 \%)$ and chromosome 10 (83\%), as the most frequent events in GBM. According to the $\mathrm{CN}$ variation observed in these chromosomes four subgroups were disclosed, revealing strong association with patients' overall survival. GBM with EGFR amplification showed longer survival times when compared to those with no amplification $(p=0.006)$, or to the other subgroups ( $p=0.0006)$.

In conclusion, our results support the concept that the characterization of genomic changes underlying GBM development, along with the recognition of genetic

\footnotetext{
* Correspondence: ines.r.crespo@gmail.com

${ }^{1}$ Centre for Neurosciences and Cell Biology, University of Coimbra, Coimbra, Portugal

Full list of author information is available at the end of the article
}

subsets within these tumors, may be useful to predict prognosis behaviour and to better stratify patients.

\begin{abstract}
Author details
${ }^{1}$ Centre for Neurosciences and Cell Biology, University of Coimbra, Coimbra, Portugal. ${ }^{2}$ Faculty of Pharmacy, University of Coimbra, Coimbra, Portugal. ${ }^{3}$ Instituto de Estudios de Ciencias de la Salud de Castilla y León, Soria, Spain. ${ }^{4}$ Centre for Cancer Research (CIC IBMCC-CSIC/USAL), Salamanca, Spain. ${ }^{5}$ Research Unit of the University Hospital of Salamanca, Salamanca, Spain. ${ }^{6}$ Neuropathology Laboratory, Neurology Service, University Hospital of Coimbra, Coimbra, Portugal. ${ }^{7}$ Neurosurgery Service, University Hospital of Coimbra, Coimbra, Portugal. ${ }^{8}$ Faculty of Medicine, University of Coimbra, Coimbra, Portugal.
\end{abstract}

Published: 24 September 2010

\section{Reference}

1. Vital AL, Tabernero MD, Crespo I, Rebelo O, Tão H, Gomes F, Lopes MC, Orfao A: Intratumoral patterns of clonal evolution in gliomas. Neurogenetics 2010, 11:227-39.

doi:10.1007/s10048-009-0217-x

Cite this article as: Crespo et al:: Identification of copy number variations of chromosomes 7, 9 and 10 in human glioblastomas by SNP-arrays. BMC Proceedings 2010 4(Suppl 2):P53.

Submit your next manuscript to BioMed Central and take full advantage of:

- Convenient online submission

- Thorough peer review

- No space constraints or color figure charges

- Immediate publication on acceptance

- Inclusion in PubMed, CAS, Scopus and Google Scholar

- Research which is freely available for redistribution

Submit your manuscript at www.biomedcentral.com/submit
Biomed Central 